\title{
An Empirical Study of Content-Based Instruction Applied in Non-English-Majored Graduate English Teaching in the Post-Massification
}

\author{
Yougen Lou \\ School of Foreign Studies, Yangtze University, Jingzhou, China \\ Email: louyougen@163.com
}

Received 14 July 2015; accepted 15 August 2015; published 19 August 2015

Copyright (C) 2015 by author and Scientific Research Publishing Inc. This work is licensed under the Creative Commons Attribution International License (CC BY). http://creativecommons.org/licenses/by/4.0/

(c) ()

\begin{abstract}
In the post-massification period, it is a beneficial attempt to the reform of English Teaching based on subject content for non-English-majored graduate students. Content-Based Instruction (CBI) has been defined as "the teaching of content information in the language being learned with little or no direct or explicit effort to teach the language itself separately from the content being taught", which can make non-English-majored graduate students not only learn subject knowledge but also improve their foreign language (English) ability in learning content. Results in this study showed that: in the post-massification period, content-based English teaching could improve the level of motivation and English language ability of students in their English learning, but CBI was not suitable for poor English learners with no good foreign language (English) basis.
\end{abstract}

\section{Keywords}

\section{CBI, Graduate English Teaching, Post-Massification Period}

\section{Introduction}

Content-Based Instruction (CBI) has been defined as "the teaching of content or information in the language being learned with little or no direct or explicit effort to teach the language itself separately from the content being taught” (Krahnke, as cited in Richards \& Rodgers, 2001). This teaching approach is considered by many researchers as an effective and realistic teaching method in terms of combining language and content learning. According to Crandall (1999), CBI can be used in various ways depending on the skills being taught and in- 
cludes not only traditional teaching methods such as grammar-based instruction or vocabulary development but also contemporary approaches such as communicative language teaching and humanistic methods. CBI is related to Krashen's "Monitor Model". Krashen (1982) emphasized ways of decreasing learner anxiety, such as providing interesting texts as well as meaningful activities, which were comprehensible to learners, and CBI had the following essential features: "learning a language through academic content, engaging in activities, developing proficiency in academic discourse and fostering the development of effective learning strategies" (Crandall, 1999). Content-Based Instruction is based on three main theories of language and four teaching models. Three main theories of language are: "language is text and discourse-based," "language use draws on integrated skills," and "language is purposeful" (Crandall, 1999). Four teaching models are "theme-based approach", "sheltered-content courses", "adjunct courses" and "language for special purposes".

CBI in foreign language teaching has been used to improve students' subject knowledge and cognitive ability and promote the improvement of its language (Mohan, 1986). CBI was born in immersion program teaching experiment in Montreal, Canada in 1960s. CBI in foreign language teaching in foreign countries had many successful examples (Benesch, 1988; Brinton et al., 1989; Kasper, 1994, 1997; Chumpavan, 2001). Some scholars (Lv, 2001; Li, 2002) in China suggested that foreign (English) language teaching form should be combined foreign (English) language with content. There were teaching researches (Yu \& Han, 2003) based on the combination of foreign language and the subject content in the college English teaching environment in China, but CBI in non-English-majored graduate students' English teaching research was still at groping stage in the post-massification period in China.

\section{Research Methods}

\subsection{Research Design}

In order to make clear that, in the post-massification period, 1) Does content-based instruction (CBI) help nonEnglish-majored graduate students improve their motivation to learn English? 2) Does content-based instruction help non-English-majored graduate students improve their English language proficiency? 3) Is CBI beneficial to all graduate students in the study in English learning? A comparative research method was used in this study. The subjects were divided into the control group (CG) and the experimental group (EG). And the conventional English teaching method was used in CG, which focused on learning the form of the language and on teachers' teaching the knowledge of the language in the text, while EG was taught by a new English teaching method, namely English teaching based on subject content.

\subsection{Subjects}

In September 2014, 115 first-year non-English-majored graduates in 3 classes from Yangtze University participated in this study. Among the 115 subjects, 60 were females and 55 males, average age 22 with Chinese as the main language. Their majors are chemistry, agriculture, plant protection, finance, biological technology. All 115 students who had learned graduate English first semester and had passed CET4 were divided into CG (57 students) and EG (58 students) randomly. Their level of education, family background, age, personality and life experiences and other factors were same, that was to say, their overall learning and cognitive abilities were almost equal. The second semester, EG were taught with the subject content course Experimental Design the English original material as the course materials in English teaching. CG were continued to learn conventional English course material Graduate English. The survey found that before the experiment, EG and CG showed no significant difference in learning motivation level $(t=.139, p=.446)$ (Table 1$)$. Meanwhile, two groups of students in English language ability were not significantly different $(t=.163, p=.968)$ (Table 3). Therefore, we can say that EG and CG are homogeneous before the experiment.

\subsection{Instruments}

The instruments used in the study were the English Learning Motivation Questionnaire, English Language Applied Ability and interviews

English Learning Motivation Gardner \& Lamber's language learning motivation, attitude/motivation test Scale AMTB (Attitude/Motivation Test Battery), as the survey tool in the study was used to measure students' English language learning motivation, and desire that the three-point Likert scale for scale, a total of 20 questions, 
which related to the motivation and desire 10 questions respectively. Prediction of internal reliability was .90, meaning that the scale display was reliable.

English Language Applied Ability. The National College English Test band 6 (2013 New Style) (full score of 710) and the National CET Oral Test (full score of 15) as the English language tools were used in this study to test the ability of students to use English. Content of CET 6 were showed in Table 2.

Interviews There were interviews with all 58 students in EG about the course experimental design and the harvest of learning English through the subject content. The teacher wrote down all interviews with all 58 students in EG about the course experimental design and the harvest of learning English through the subject content.

\subsection{Data Collection and Analyses}

Before the research experiment (September 2013) and after the experiment (February 2014) two surveys on English learning motivation and two tests on English language applied ability were conducted to compare changes between the two groups of students in English learning motivation and the ability to use English. In this study, social scientific software SPSS 17.0 was used for statistical analysis to the collected data, the results showed that, the internal consistency reliability of the use of questionnaires and survey papers reached more than .77, indicating that the test results were reliable. In order to find out CBI proved superior to the conventional teaching (such as grammar- translation) method, comparison of Means was adopted to compare two groups of

Table 1. Test of English learning motivation between CG and EG.

\begin{tabular}{|c|c|c|c|c|c|c|c|}
\hline & & \multicolumn{2}{|c|}{$\mathrm{CG}(\mathrm{N}=57)$} & \multicolumn{2}{|c|}{$\mathrm{EG}(\mathrm{N}=58)$} & \multirow[b]{2}{*}{$\mathrm{t}$} & \multirow[b]{2}{*}{$\mathrm{p}$} \\
\hline & & M & $\mathrm{S}$ & M & $\mathrm{S}$ & & \\
\hline & MS & 2.21 & .42 & 2.19 & .50 & .374 & .182 \\
\hline \multirow[t]{3}{*}{ Pretest } & $\mathrm{DL}$ & 2.24 & .43 & 2.26 & .49 & -.235 & .264 \\
\hline & Total & 4.35 & .80 & 4.45 & .91 & .139 & .446 \\
\hline & MS & 2.19 & .45 & 2.28 & .46 & -1.62 & .053 \\
\hline \multirow[t]{2}{*}{ After the experiment } & D L & 2.24 & .43 & 2.35 & .48 & -1.17 & $.022 *$ \\
\hline & Total & 4.43 & .85 & 4.63 & .86 & -2.79 & $.025^{*}$ \\
\hline
\end{tabular}

*Means $p \leq .05$; CG for Control Group; EG for Experimental Group; MS for Motivation Strength; DL for Desire of Learning.

Table 2. Comparison of teaching content and teaching process between CG and EG.

\begin{tabular}{|c|c|c|}
\hline Items & CG & EG \\
\hline $\begin{array}{l}\text { Teaching } \\
\text { Content }\end{array}$ & $\begin{array}{l}\text { Priority to English language knowledge, interpretation of } \\
\text { the text content for students acquiring language knowledge }\end{array}$ & $\begin{array}{l}\text { Priority to experimental design knowledge and } \\
\text { linguistic knowledge as complementary }\end{array}$ \\
\hline Schedules & $\begin{array}{l}2 \text { hours for the teacher's teaching reading and writing (the } \\
\text { teacher explaining language points, students answering a } \\
\text { few questions); } 2 \text { hours for non-English-majored graduate } \\
\text { students listening to listening material from textbooks and } \\
\text { College English Test (CET) Level } 6\end{array}$ & $\begin{array}{l}2 \text { hours for the teacher's teaching reading and writing } \\
\text { (the teacher explaining related chapters, at the same } \\
\text { time, students exploring chapters content and design } \\
\text { of experiment in English); } 2 \text { hours for listening (via } \\
\text { Internet to download audio and video data to discuss } \\
\text { design of experiment) }\end{array}$ \\
\hline $\begin{array}{l}\text { Language } \\
\text { Material }\end{array}$ & $\begin{array}{l}\text { Domestic non-English-majored graduate students textbooks } \\
\text { and College English Test (CET) Level } 6 \text { papers }\end{array}$ & $\begin{array}{l}\text { Original English textbooks, English audio and video } \\
\text { materials, and English programs on the network }\end{array}$ \\
\hline $\begin{array}{l}\text { Teaching } \\
\text { Language }\end{array}$ & Combination of Chinese and English & English \\
\hline $\begin{array}{l}\text { Teaching } \\
\text { Activities }\end{array}$ & $\begin{array}{l}\text { Priority to the explanation, and little interaction between } \\
\text { teachers and students }\end{array}$ & $\begin{array}{l}\text { Teacher's explanation as complementary; more } \\
\text { presentations and discussions between students; } \\
\text { Interaction between teachers and students; } \\
\text { Communication between students }\end{array}$ \\
\hline $\begin{array}{l}\text { Teaching } \\
\text { Means }\end{array}$ & $\begin{array}{l}\text { Reading and writing lessons in regular classrooms; } \\
\text { listening lessons in language-learning lab }\end{array}$ & $\begin{array}{l}\text { All the lessons in classrooms with network and } \\
\text { multimedia equipment }\end{array}$ \\
\hline
\end{tabular}


graduate students' average scores of their pretest and after the experiment on the basis of two samples. And the independent sample T-test was adopted to exanimate if there were significances between CG and EG before the experiment and after the experiment.

\section{Course Content and Teaching Organization Process}

This experiment was carried out a semester, the implementation details were shown in Table 2. English classroom teaching time for CG and EG was, respectively, 4 hours per week, reading, and writing listening and speaking lessons taught by the same English teacher. EG was taught with teaching mode CBI, Experimental Design used as subject material, and the experimental accuracy, the experiment results of statistical analysis, random design, and factor experiment design involved as the subject content. Students in EG read the content of the relevant chapters before class, teaching activities for EG in class were teachers answering questions from students or solving problems from students who did not understand the subject content they read, a topic presentation made by students from EG, group discussion and question answering between students in EG and so on.

In class, the teacher's explanation for subject content and student's statements for subject content were conducted in multimedia network classroom, with broadcast audio and video materials to help students understand the course content knowledge. In EG, English used as the teaching language in teaching activities, students in EG were encouraged by the teacher to communicate freely about the subject content in English, and to interpreter, induce and analyze the facts and opinions in the subject content. Contemporary Graduate English (intensive reading) used as the teaching material for CG, teachers mainly adopted the combination of teaching methods for CG: grammar-translation and listening, and explained language knowledge and the text content, students answered the questions from the teacher on the text.

\section{Results}

In this study, social sciences software SPSS17.0 was used for statistical analysis to collected data to obtain relevant results, and the results were discussed and analyzed.

\subsection{English Learning Motivation}

After the half-year experiment, students' English learning motivation were improved between CG and EG. At the end of the experiment, CG was lower than EG in the overall level of learning motivation $(t=-1.62, p=.053)$, while CG was less strong desire than EG to learn English $(t=-1.17, p=.022)$ (Table 1).

\subsection{English Applied Ability}

As showed in Table 3, after half-year experiments, the ability to use the English language in CG and EG were improved, but the ability to use English of the students in CG was, in general, lower than EG, which showed a significant difference $(t=-6.237, p=.034)$. Specifically, CG was significantly inferior to EG compared to the increase in the output of the skills, such as composition $(t=-2.082, p=.042)$ and oral $(t=-2.107, p=.0348)$, indicating that students in EG in English writing skills and spoken English skills had been significantly improved. CG was significantly inferior to EG on the skills of reception, such as hearing $(t=-2.121, p=.037)$ and reading $(t=-.585, p=.047)$, which showed that EG in English Listening comprehension and reading comprehension had improved significantly. While there was no significant difference $(t=.656, p=.513)$ in the integrated skills (translation) between CG and the experimental group.

\subsection{Interview}

After the experiment, the teacher had interviews with EG of 58 students about the course experimental design and the harvest of learning English through the subject content. 49 students from EG said that their English ability (composition, listening, reading, translation and oral English) was improved a lot. 9 students from EG said that their English ability (composition, listening, reading, translation and oral English) was improved a little.

\section{Discussion}

Needs to promote the development of learning motivation, and learning motivation was an important factor in 
Table 3. Test of English applied ability between CG and EG.

\begin{tabular}{|c|c|c|c|c|c|c|c|}
\hline & & \multicolumn{2}{|c|}{ CG $(\mathrm{N}=57)$} & \multicolumn{2}{|c|}{$\mathrm{EG}(\mathrm{N}=58)$} & \multirow[b]{2}{*}{$\mathrm{t}$} & \multirow[b]{2}{*}{$\mathrm{p}$} \\
\hline & & M & S & M & S & & \\
\hline \multirow{6}{*}{ Pretest } & Composition & 87.17 & 9.04 & 86.60 & 9.86 & .277 & .837 \\
\hline & Listening & 141.19 & 12.39 & 139.55 & 10.23 & .663 & .175 \\
\hline & Reading & 147.12 & 11.82 & 148.60 & 11.28 & -.585 & .657 \\
\hline & Translation & 44.55 & 4.46 & 44.64 & 4.97 & -.092 & .658 \\
\hline & Oral English & 9.40 & 1.06 & 9.42 & 1.12 & -.100 & .958 \\
\hline & Total & 429.43 & 38.77 & 428.81 & 37.46 & 0.163 & .968 \\
\hline \multirow{6}{*}{$\begin{array}{l}\text { After the } \\
\text { experiment }\end{array}$} & Composition & 85.21 & 8.24 & 89.12 & 8.32 & -2.082 & $.042 *$ \\
\hline & Listening & 143.1 & 9.45 & 145.2 & 9.12 & -2.121 & $.037 *$ \\
\hline & Reading & 149.02 & 10.82 & 151.210 & 9.28 & -.585 & $.047 *$ \\
\hline & Translation & 45.93 & 5.75 & 45.14 & 5.21 & .656 & .513 \\
\hline & Oral English & 9.46 & 1.32 & 9.57 & 1.38 & -2.107 & $.038 *$ \\
\hline & Total & 432.72 & 35.58 & 440.24 & 33.31 & -6.237 & $.034 *$ \\
\hline
\end{tabular}

*Means $p \leq .05$; CG stands for Control Group; EG stands for Experimental Group.

the development of language learning. Seen in Table 1, we know that, after half-year experiment CG was lower than EG in the overall level of learning motivation, especially the desire to learn English.

The main reasons are:

First, English courses teachers were required by non-English-majored graduate students. When teaching content related to the interest of learners, students would have a strong desire to learn subject content, this correlation was a prerequisite for maintaining long-term motivation to learn. Some of students in EG already had a strong interest in learning English, the teachers chose English language as a medium to teach curriculum content and design of experiments to help students learn needed academic subject knowledge. After the experiment, talked with the students in EG we knew that they thought learning English as a medium to gain academic subject knowledge, which promoted the development of their English learning motivation.

Second, the course content was from the real experimental content and language content. In this study, original content-based English teaching materials were used for English textbooks, which was helpful for students to develop their own experimental design. Students' learning motivation changed gradually from the instrumental motivation to integrative motivation.

Therefore, the combined effect of the differences on overall academic achievement between the two groups of students was contributed to the internal and external factors from two groups of learners in the experiment. Students in the experimental listened to teachers explain the subject content knowledge in English, after class they listening to and watching English programs related to the course, so that they were in English listening environment to enhance their listening ability of a great help.

After the experiment, the researcher in this study, after the conversation with students in EG, knew that some graduate students with poor basic English foundation in this study said that they felt English learning pressure increased and their ability to use the English language to be improved was not obvious in CBI. This indicated that the course content was limited to help students with poor English basis.

\section{Limitations and Suggestions}

Though the present study has provided a comparatively detailed description of CBI applied among some firstyear non-English-majored graduate students, there are still some limitations of the study. Having the limitations in mind, suggestions for further research, therefore, can be put forward at the same time in order to achieve a lot thorough understanding of CBI

Firstly, being time limitation (only half year) and other practical restrictions such as the subjects in the study 
consisted of only 115 non-English-majored graduate students in one university need to be broadened in further research.

Secondly, the instruments used to investigate non-English-majored graduate English teaching with CBI involve structured questionnaire, tests and interviews. The study would be much better, if it were combined with other instruments such as observation, verbal report. More instruments should be used in investigation in further research.

Finally, CBI applied in non-English-majored graduate English teaching can improve non-English-majored graduate students' English learning and their course learning, but CBI also works for other subjects such as undergraduate students, we need further research.

Despite of the restraints of the study, it is hoped that it can offer some guidelines for further research on CBI applied in English teaching.

\section{Conclusion}

This study was designed to explore CBI in English teaching in the post-massification period. Results in this study showed that: in the post massification period, content-based English teaching could improve the level of motivation and English language ability of students in their English learning, but CBI was not suitable for poor English learners with no good foreign language (English) basis.

\section{References}

Benesch, S. (1988). Linking Content and Language Teachers: Collaboration across the Curriculum. In S. Benesch, (Ed.), Ending Remediation: Linking ESL and Content in Higher Education. Washington DC: Teachers of English to Speakers of Other Languages.

Brinton, D. M., Snow, M. A., \& Wesche, M. B. (1989). Content-Based Second Language Instruction. New York: Harper \& Row.

Chumpavan, S. A (2001). Comparative Study of Two English as a Foreign Language (EFL) Programs: Non-Content-Based and Content-Based at the University Level in Thailand. PhD Dissertation, Normal: Illinois State University.

Crandall, J. (1999). Content-Based Instruction (CBI). Concise Encyclopedia of Educational Linguistics (pp. 208-604). Oxford, UK: Cambridge University Press.

Kasper, L. F. (1994). Improved Reading Performance for ESL Students through Academic Course Pairing. Journal of Reading, 5, 376-384.

Kasper, L. F. (1997). The Impact of Content-Based Instructional Programs on the Academic Progress of ESL Students. English for Specific Purposes, 4, 309-320. http://dx.doi.org/10.1016/S0889-4906(97)00035-5

Li, L. S. (2002). Sustained-Content Language Teaching Mode and Its Enlightenment to College English Teaching Reform in China. Foreign Language World, 4, 36-40.

Lv, L. H. (2001). The Integration of Language and Content-Trend of Foreign Language Teaching Reform. Global Edu- cation, 8, 52-56.

Mohan, B. A. (1986). Language and Content. Reading, MA: Addison-Wesley.

Richards, J., \& Rodgers, T. (2001). Approaches and Methods in Language Teaching (p. 204). New York: Cambridge University Press. http://dx.doi.org/10.1017/CBO9780511667305.021

Yu, L. M., \& Han, J. X. (2003). Based on Course Teaching in Ottawa and Its Enlightenment. Foreign Language Teaching and Research, 3, 465-468. 